\title{
John Lagerwey, China: A Religious State
}

Hong Kong, University of Hong Kong Press, 2010, 238 pp.

\section{David Palmer}

\section{OpenEdition}

\section{Journals}

Electronic version

URL: http://journals.openedition.org/chinaperspectives/5975

DOI: 10.4000/chinaperspectives.5975

ISSN: 1996-4617

\section{Publisher}

Centre d'étude français sur la Chine contemporaine

\section{Printed version}

Date of publication: 1 October 2012

Number of pages: 86-87

ISSN: 2070-3449

\section{Electronic reference}

David Palmer, «John Lagerwey, China: A Religious State », China Perspectives [Online], 2012/3 | 2012, Online since 01 October 2012, connection on 24 September 2020. URL : http://

journals.openedition.org/chinaperspectives/5975; DOI : https://doi.org/10.4000/chinaperspectives. 5975

This text was automatically generated on 24 September 2020.

(c) All rights reserved 


\section{John Lagerwey, China: A Religious State}

Hong Kong, University of Hong Kong Press, 2010, 238 pp.

\section{David Palmer}

1 China: A Religious State is the published version of a series of lectures given by John Lagerwey at the Chinese University of Hong Kong and the University of Hong Kong around 2008, offering a comprehensive view of the religious dimensions of Chinese state and society throughout its long history as well as in the deep structures of traditional local communities.

2 The book is immensely rich in its breadth and in the profusion of historical and ethnographic details offered by one of the very few scholars in the world with a virtually unsurpassed mastery of both classical sinological scholarship on Chinese (and Daoist) religious history as well as the ethnography of local ritual and society. Indeed, Lagerwey, who has just

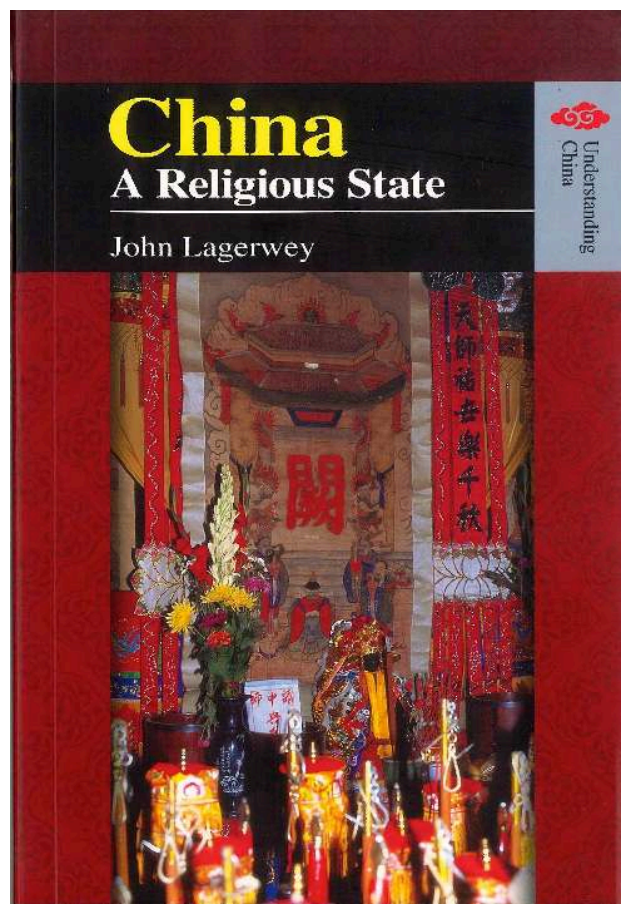
retired as the holder of the prestigious Chair of Daoism and Chinese Religions at the École Pratique des Hautes Études, and is now a Professor at the Chinese University of Hong Kong, has, as an early collaborator of the renowned Daoist scholar Kristofer Schipper, conducted authoritative studies on the Daoist Canon as well as participant observation of Daoist priests in Taiwan and Fujian. He later initiated a wave of local ethnographies and folklore studies in Southeast China, publishing more than 30 volumes of field reports and oral histories by local scholars he 
has trained and nurtured. Most recently, he has been editing a monumental history of Chinese religion, with substantial contributions by virtually all of the world's leading scholars in the field.

China: A Religious State draws on this massive body of research; though short, the book is so replete with historical, ritual, and ethnographic detail that the reader may easily get lost in the thick jungle of Chinese religion, losing sight of the big picture. Such is, perhaps, one of the objectives of the book - to show that not only is the conventional intellectual view of China (whether Chinese or Western) of a civilisation in which religion is but a marginal dimension completely false, but that this religious dimension is so astonishingly rich and diverse that it cannot be reduced to any simple statement or formulation. Reading China: A Religious State, we realise that if materials on China had been available to Sir James George Frazer over a century ago, he could easily have doubled the length of his Golden Bough!

It would be impossible to summarise this detail in a brief review; I will limit myself to raising some questions or musings that arose to me after reading each chapter of the book.

5 The Introduction argues that "China is a religious state and Chinese society is a religious society;" China is a sacred space traditionally conceived as a "continent of spirits" (shenzhou 神州), a notion that should not be treated as a "mere" metaphor. It is now known that the image of a rational, non-religious Chinese civilisation derives from the Jesuit project of marrying Christianity with a secularised Confucianism - but Lagerwey focuses here on the Confucians' alliance with the Jesuits and their participation in their deception. He argues that modernity began when symbol and reality were separated, when the Protestant reformation asserted that the sacraments are "nothing but symbols" or "mere metaphor," devoid of intrinsic spiritual power. Lagerwey reminds us that the idea of ritual as "nothing but" symbolism dates back to Xunzi and Confucius, who advocated that ritual should be practiced to regulate the emotions, "as if" the spirits of the ancestors were present, but not truly believing so (p.3). When the Jesuits arrived in the mid sixteenth century, Ming neo-Confucianism was in full swing and "the neo-Confucian elite had its own project, namely, to transform society by ridding it of the rituals of shamans, Buddhists, and Daoists, and putting Confucian rituals in their place" (p. 3). Thus, "neo-Confucian rationalism" was ready to "make a deal" with "Thomist rationalism" as part of its project of replacing China's gods with neo-Confucian ancestor worship. Lagerwey thus argues that the Jesuit-Confucian encounter was the meeting of two distinct and unwitting secularising tendencies, one of which, the Chinese, had been advancing for 2,000 years.

This begs the question, however, of why, after 2,000 years, the Confucian rationalising project had made so little progress by the time the Jesuits arrived - we now know that China, in late imperial times, was an intensely religious society, as this book demonstrates. Perhaps the answer lies in the fact that, while Confucian learning urged the gentleman to participate in rituals as if the ancestors or gods were present, they did not object to the common people believing that the ancestors and spirits are really present, and regulating their behaviour accordingly - yi shendao shejiao以神道設教. Thus, under Chinese orthopraxy, rituals should be maintained, and what is important is to participate, with the freedom to consider them either magically efficacious or "merely" symbolic and socially functional. Thus, while the secularising tendency is always present in Confucianism, the secularising rupture is always absent. Hence the 
modern perplexity about whether or not Confucianism is or is not religious/a religion. The Western experience, however, has been one of radical ruptures - first, as Lagerwey notes, differences of understanding and belief about the possibility or not of the "transubstantiation" of the bread and wine could not be tolerated among the participants of the same ritual service, so that separate and warring Catholic and Protestant churches were needed - and later, again, as atheists and religious believers could not participate together in the same rituals, entirely distinct and opposed institutions and ideologies had to be created for the "religious" and the "nonreligious." The apparent affinities between Jesuit and Confucian rationalism thus mask a substantive difference, which hinges on the Confucian acceptance of ambiguity, ambivalence, and indeterminacy in the name of social harmony.

7 Chapter One, "A Brief History of the Pantheon: Ancestors and Gods in State and Local Religion and Politics," presents a rapid overview, from pre-imperial to late imperial times, of state-religion relations in China. One focus is on the Chinese rulers' deity worship, noting how, with each new regime or dynasty, or sometimes with the accession of a new emperor, the ruler made significant modifications to the religious system, often sacrificing to different deities and supporting some deities and sects while suppressing others, who may have been favoured by the previous ruler. As Lagerwey argues, in China, "state=church" (p. 49), and "from the Shang ancestors to the Longmen sect, this is a constant feature in Chinese religious history: it is dominated by political decisions" (p. 54).

This fact raises several questions related to the modalities of the religious behaviour of the imperial throne. For instance, an essential component of the Emperor's assertion of territorial sovereignty was the worship, by the Emperor or his officials, of local or regional territorial deities - such as the City Gods of each town, or the gods of the Five Marchmounts (wuyue五岳). But how can imperial sovereignty be signified through the supreme emperor or his agents worshipping lower, more local deities? Who, of the emperor or the deity, is subordinating himself to whom? And why did the imperial regime so often change the "supreme" god that it worshipped - from Di 帝 to Tian 天, Taiyi 太一, Laozi 老子, Haotian Shangdi 浩天上帝, Xuantian Shangdi 玄天上帝, and so on? If the emperor, as the supreme power on earth, needed to worship his counterpart in Heaven, why change his name and cult? Perhaps we need here to reconsider our concept of the "worship" and "cult" of a god, possibly derived from the notion of the Abrahamic God who demands absolute submission, and for whom worship is the embodied expression of submission. Perhaps something more subtle and ambiguous is at play in the Chinese case - sacrifice being an instance of "gifting" and "hosting" in an anthropological sense, the ritual formation and renewal of an alliance in which both parties possess, maintain, and exchange power (see forthcoming work by Adam Chau). A Chinese deity is a nexus of social relations, a node of spiritual powers related to place, and a materialised body of narratives and memories - all linked to at least one organised interest group in society. Thus, the emperor's sacrifice to a deity would be the ritual construction and maintenance of a political alliance with this network of powers. Imperial sovereignty is thus maintained by keeping itself at the centre of a vast system of localised networks of powers. With a new dynasty or regime, new networks of power need to be established - this might partially involve retaining portions of the old regime's network, but also partially involve creating a new one. Which deities and sects would rise or fall in this process would be the result of the give and take between powers and interests. While we tend to conceive of the political game as a negotiation 
between humans, in China it might be useful to see the role of deities, rituals, and temples as mediating objects in the political game.

Such a perspective might give us insights on "Daoist Ritual in Social and Historical Perspective," which is the subject of Chapter Two. Discussing the Daoist Heavenly Masters tradition 天師道, Lagerwey stresses the oft-noted bureaucratic organisation of the pantheon and the role of the Daoist priest as an official mandated to send forms and petitions on behalf of the people to the relevant offices of the celestial government. Daoist ritual mediates a celestial world of official documents, record-keeping, and lawsuits, combined with a concern with healing and immortality. With the revelation of the Lingbao 霝寶 Canon around AD 400, Mahayana Buddhist concerns about karma, cosmic retribution, and universal salvation are integrated into Daoist ritual, turning it into a "universal religion" (p. 70). Through further changes and transformations, we see Daoist ritual evolving in many directions, ranging from refined court ceremonies to integration with the local deities and spirit-mediums of village religion. There we see the dual role of the Daoist priest, as minister (chen 臣) in the sublimated court of Dao, and as general (jiang 將) vis-à-vis the local spirits and demons - a complementary distinction played out in the civil-martial (wen/wu 文武) structure of much village ritual today. Local spirits may be either absorbed into the Daoist hierarchy as lowerranked minions or fought as unruly, bloodthirsty demons. The role of the Daoist ritual institution in negotiating relationships, alliances, or conflicts between local and universal deities and forces is clear. It thus played an indispensable role both for local communities and for the imperial throne in their formation of religio-political alliances, providing a common but multivocal ritual and symbolic language for working through their relationships.

In chapters Three and Four, "Festivals in Southeastern China" and "On the Rational Character of Chinese Religion," we are treated to a cornucopia of ethnographic titbits drawn from dozens of villages, towns, county seats, and mountain temples. Faced with the bewildering diversity of material, Lagerwey concludes that "The first observation to be made of this material concerns its richness, the second its unity."

How can we make sense of both the unity and diversity of these local festivals? A few thoughts come to my mind: on the one hand, all of these popular customs are rooted in the same Chinese cosmology and "demonological paradigm," to use Barend J. ter Haar's formulation: the festivals have both a life-affirming, life-generating function and an exorcistic or prophylactic function of protecting the community from ghosts and demons, which are associated with the dangerous world outside the community. Local deities have an intimate connection to the demonic realm: sometimes former demons themselves, they know how to fight the evil forces. Hence, they make good allies for communities in search of a protector. But, lest they remain too close to the wild and demonic ways, they also need to be firmly anchored to the realm of order and civilisation - hence the attempts of both Daoism and the imperial state to integrate them into their pantheons and ritual systems.

12 I have suggested that the "cult" of a Chinese deity should be seen as a reciprocal, gifting alliance between a human group and the deity, in which both parties are seen as having some power over the other. On the side of the human groups, we see, as Lagerwey points out, the sophisticated methods by which, through the festivals of the deities, they organise their own alliances between social groups - be it the different lineages of a village, the different villages of an irrigation system, the different streets 
of a town, or even the different segments of a street. The specific setup - which groups will take turns to organise the procession, or the route and order of the procession, or the amount each group contributes to the overall cost - is a function of the balance of power between the groups, both in the past and in the present. The configuration also reflects, or contains traces of, the relationships between the groups as they stood several generations earlier, but they may also be modified to reflect more recent changes. The deities and their festivals are thus structuring mediators, giving form to the community's relationships within the sub-groups that compose it, and its outer boundaries and negotiations with other groups and with the demonic world outside. The infinite possible combinations, even within a small geographic area, of ecological niches, historical particularities, and social groups and subgroups can thus give rise to endless permutations, always varying in their "words" and "sentences," as Lagerwey puts it, according to the same basic grammar of Chinese religious cosmology.

13 To conclude, then, China: A Religious State is an impassioned argument for putting religion at the centre of our understanding of chinese culture and society, from the smallest village to the imperial state. But to admit to such a perspective is only the beginning of a new path of inquiry - since "religion," as we find it in China, in its bewildering diversity and complexity, is a far cry from the simplistic notions we have inherited from Western experience and secularist ideology highlight a sociological viewpoint and avoid reflection on the political regime.

\section{AUTHOR}

\section{DAVID PALMER}

Assistant Professor in the Department of Sociology at the University of Hong Kong (palmer19@hku.hk). 